\title{
The UK Independence Party: understanding a niche party's strategy, candidates and supporters
}

Philip Lynch, Richard Whitaker and Gemma Loomes

\begin{abstract}
The UK Independence Party (UKIP) came second in the 2009 European elections, but niche parties associated with a single issue face a dilemma about how to progress. On one hand, if they move too far beyond their core issue, they risk losing their distinctive position and support base. On the other, if they are to grow their representation, they need to develop a broader platform and this can provoke internal tensions. We assess the political attitudes and views on party strategy of UKIP candidates using surveys at the 2009 European and 2010 general election, and compare them with the views of UKIP supporters using opinion poll data. We demonstrate that UKIP's candidates and supporters are closely aligned, with both groups being strongly Eurosceptic, favouring tighter immigration policies and distrusting the main parties. We also show that UKIP's leadership and candidates wish to extend the party's narrative, but differences remain over what issues it should focus on, as well as over competition with the Conservatives and UKIP's role in the European Parliament.
\end{abstract}




\section{The UK Independence Party: understanding a niche party's strategy, candidates and supporters}

The UK Independence Party (UKIP) achieved its best election performance in the 2009 European Parliament elections, coming second with $16.5 \%$ of the vote. As a 'hard' Eurosceptic party committed to withdrawal from the European Union (EU), ${ }^{1}$ it mobilised Eurosceptic sentiment and capitalised on the unpopularity of the main parties. Niche parties such as UKIP whose appeal is strongly linked to a single issue face a dilemma about how to progress. ${ }^{2}$ If they move too far beyond the issue for which they are best known, they risk losing their distinctive position and support base, but if they are to expand their representation, they need to develop a wider range of policies and this can cause internal disagreements. Using original surveys of UKIP candidates at the 2009 European and 2010 general election, and a series of non-attributable interviews with UKIP MEPs, candidates and officials, we assess the political attitudes and views on party strategy of UKIP candidates. We then compare these with the views of UKIP's supporters using opinion poll data. This represents the first systematic attempt to map UKIP candidates' views, to compare them with those of UKIP supporters, and to assess the attitudes of UKIP voters at the 2010 general election. We show that UKIP's candidates are united around its core policy of withdrawal from the EU and the need to campaign on issues beyond this, but that there are differences on how far the party engages with the European Parliament (EP) and how it deals with the Conservative Party. We also demonstrate that UKIP's candidates and supporters are closely aligned, with both groups being strongly Eurosceptic, favouring tighter immigration policies and distrusting the main parties.

\section{Niche party behaviour}

The academic literature on the new and small parties emerging in Europe in recent decades shows that these niche parties behave differently to their mainstream counterparts. Meguid defines niche parties as those with a distinctive focus on a limited set of issues which lie beyond the traditional class cleavage and are largely ignored by mainstream parties. ${ }^{3}$ Adams et al. adopt a broader definition of non-centrist parties, ${ }^{4}$ while Wagner emphasises their focus on non-economic issues. ${ }^{5}$ Green, ethno-regionalist and radical right parties are typically identified as niche parties. Hard Eurosceptic parties such as UKIP would also appear to qualify given their focus on an issue that lies on a comparatively new anti-European integration versus pro-integration cleavage, yet they barely feature in these studies. UKIP is absent from some of the data sets on party positioning, ${ }^{6}$ and existing studies tend to focus on parties with national representation. UKIP is, though, included in a 2010 study of niche party behaviour in the EP. ${ }^{7}$

Hard Eurosceptic parties form a distinctive sub-set of niche parties. Although strongly associated with the issue of European integration, they cover a wider range of policies than many niche parties. The extension of EU competences has seen UKIP highlight the costs of membership, criminal justice, immigration, agriculture and fisheries policies. Hard Eurosceptic parties also differ from other niche parties (e.g. green parties) in that they are not part of an extensive or coherent party family. 'Soft' Eurosceptic parties oppose further European integration but are not opposed to the EU in principle and opposition to further integration is not their primary concern. ${ }^{8}$ Ideological differences between UKIP and other hard Eurosceptic parties, such as the left-leaning Swedish June List, mean that they have not been allies in the EP.

The behaviour of niche parties differs from that of mainstream parties in a number of ways. Political parties have three broad objectives - policy, office and votes. ${ }^{9}$ Policy objectives are particularly important for niche parties given their origins as a distinctive voice on a new issue and the strong feelings this engenders for their members and supporters. Whereas moving closer to the median 
voter can bring electoral reward for mainstream parties, evidence suggests that niche parties lose votes and suffer internal divisions if they moderate their core position. ${ }^{10}$ Policy and vote-seeking objectives thus suggest that niche parties should focus on the issue on which they have a radical and distinctive position. Electoral success is, however, difficult to achieve if this issue has low salience. UKIP performs significantly better in European elections than general elections where Europe is not a prominent issue.

To understand niche party behaviour, we must also take account of the positions adopted by rival parties. Mainstream parties can limit a niche party's appeal by ignoring that party's distinctive issue or by establishing ownership of it. ${ }^{11}$ In the case of UKIP, the Conservatives have adopted a soft Eurosceptic position and lowered the salience of the European issue. If their core issue has only low salience, the limited resources and media exposure of niche parties are obstacles to their agendasetting capacity.

Most niche parties develop office-seeking objectives as their policies are either ignored or adopted in a diluted fashion by mainstream rivals. To secure representation in a majoritarian system, niche parties must both push their distinctive issue up the national political agenda and build grassroots support locally. Niche parties with seats at Westminster (e.g. the Scottish National Party and Greens) have successfully combined a distinctive message with effective targeting of constituencies. ${ }^{12}$ To maximise its influence on the debate about EU membership, UKIP must win seats in the House of Commons, but it has not translated success in European elections into the domestic arena.

Representation in the EP provides hard Eurosceptic parties with resources, but poses awkward questions about the extent to which they should engage with EU institutions. ${ }^{13}$

This literature leads us to several expectations about UKIP's strategy and the difficult choices it faces. First, as hard Eurosceptic parties experience difficulties over how far to engage with the EP, we would expect to see differences within UKIP over issues such as working in a party group in the EP and membership of a transnational party. Second, if UKIP is pursuing office, and this requires campaigning on policies beyond the low salience issue of European integration, we expect candidates to favour an expansion of UKIP's narrative but also anticipate some differences over the issues it should pursue. Third, if there is conflict between pursuing office at Westminster and achieving the policy goal of withdrawal from the EU, we expect some disagreement over UKIP's relationship with Eurosceptics in other parties, particularly the Conservatives.

In order to assess how UKIP has responded to the challenges faced by niche parties in pursuing policy, vote and office objectives, we explore how UKIP has sought to advance its core message of withdrawal from the EU while also broadening its narrative. UKIP's approach to party competition with its main rivals is also examined, as is its strategy for securing and utilising representation in Europe and domestically. We consider the views of UKIP's voters in order to assess how an expansion of its policy might be successful. We start with an overview of the party's development.

\section{UKIP's development}

UKIP was formed in 1993 by Alan Sked in the wake of the ratification of the Maastricht Treaty. It was overshadowed in the 1997 general election by the Referendum Party but this was wound up after Sir James Goldsmith's death, helping UKIP become the predominant Eurosceptic voice in the party system. It won three seats in the EP in 1999 before a surge in support in 2004 brought $16 \%$ of the vote, and UKIP then came second in 2009. General election performances have been less impressive. UKIP was fourth-placed in nationwide share of the vote in 2010 , polling $3.2 \%$ but failing to win a seat. 
Like many small parties, UKIP has suffered internal disputes over its direction and had frequent changes of leader. ${ }^{14}$ Robert Kilroy-Silk, the former Labour MP and television presenter, was a media star of the 2004 European elections but his attempt to seize the leadership was frustrated and he left the party. In his first period as leader (2006-09), Nigel Farage sought to shed UKIP's image as a single-issue party. Policies such as a flat tax, a five-year freeze on immigration and opposition to identity cards were presented within a populist anti-establishment narrative that criticised the 'Lib/Lab/Con' for ignoring popular concerns about the EU and immigration. This was evident in the 2009 European elections when MPs' expenses diverted attention from the European issue, and the 2010 general election when UKIP invited voters to 'Sod the Lot'. UKIP gained representation at Westminster when former Conservatives Lord Pearson of Rannoch and Lord Willoughby de Broke joined in $2007 .^{15}$

Farage stood down in 2009 to focus on his role in the EP and campaign in Buckingham. Pearson succeeded him and campaigned for greater use of referendums and a ban on the wearing of the burqa in public. The latter introduced a prominent theme of the populist radical right; ${ }^{16}$ the former reinforced UKIP's anti-establishment message although an Old Etonian peer was hardly the most persuasive mouthpiece for this. ${ }^{17}$ Pearson was uneasy with the demands of leadership, memorably telling BBC interviewer Jon Sopel that he had not fully read UKIP's manifesto. He resigned in August 2010 and Farage was re-elected leader.

\section{UKIP candidates' survey}

To understand views on party policy and strategy within UKIP, we conducted surveys of its candidates for the 2009 European and 2010 general election. We focus on candidates' views on three strategic issues: (1) the role of UKIP MEPs; (2) whether and how UKIP should expand its range of policies, and (3) competition between UKIP and its principal rivals, particularly the Conservatives, but also the British National Party (BNP) and Labour.

Surveys were conducted using the online tool Survey Monkey. ${ }^{18}$ Emails were sent to candidates in three waves before, during and after the campaigns. Where email addresses were unavailable, postal surveys were sent. ${ }^{19}$ The response rate for the survey of European election candidates was $68 \%$; for the general election survey it was $53 \%$ of all candidates (55\% of those contacted). The surveys asked about candidates' views on European integration, political attitudes, party competition, and personal background. Of the general election respondents, 265 identified their constituency and a further nine the region where they were standing, allowing us to identify the region of all but $6 \%$ of respondents. Response rates for the general election survey were highest from candidates in Scotland (61\%) and the South East (59\%) and lowest from London (37\%) and the West Midlands (40\%). $12 \%$ of respondents were women, compared to $15 \%$ of all UKIP candidates. Chi-squared tests of the representativeness of the sample compared with the population of UKIP's general election candidates in terms of sex and region indicate that the survey is representative on these variables. ${ }^{20}$ Unless stated, data presented are from the general election survey as this is the most recent and had the most respondents. There were few significant differences between the responses of European and general election candidates. This section also draws on non-attributable interviews with UKIP MEPs, candidates and officials.

\section{UKIP in the European Parliament}

Whether UKIP should take up seats in the EP was a thorny issue in the party's early days. Those in favour claimed it would bring financial benefits, enhance the party's profile and allow it to better inform voters of the costs of EU membership. Generous salaries and expenses may be attractive to MEPs but have caused unease, particularly when Tom Wise was jailed for expenses fraud in 2009. 
Nonetheless, $91 \%$ of survey respondents agreed/strongly agreed that 'UKIP MEPs should take their seats in the European Parliament' (see Table 1) confirming that it is the settled will of the party.

[Table 1 about here]

The debate has moved on to the role of MEPs, group membership, and membership of a 'European political party'. UKIP MEPs approach their role differently. For instance, Marta Andreasen, a former European Commission chief accountant, is active on the Budgetary Control Committee, whereas Farage uses plenary sessions to generate publicity. Our survey of European election candidates asked about the importance of roles performed by MEPs. Articulating the Eurosceptic case and representing the national interest scored highly, but only a minority believed working on EU legislation was of great importance (see Table 2).

\section{[Table 2 about here]}

Membership of a group in the EP has brought additional finance, speaking time for the leader and access to influential positions (e.g. on the Conference of Presidents which is responsible for the EP's organisation). But UKIP has few natural allies in the EP as it is unusual in being born solely from Euroscepticism and committed to withdrawal. The hard Eurosceptic Danish People's Movement against the EU is a single-issue party but sits in the European United Left-Nordic Green Left group. Most Eurosceptic parties in the EP are soft Eurosceptics favouring reform of the EU. For them, Euroscepticism is one of a set of positions or the result of strategic decisions by the leadership rather than their defining feature. In the 2004-09 EP, UKIP was the largest party in the Independence/Democracy group of 37 MEPs from 10 Member States but poor election results saw the group collapse. UKIP played a lead role in forming the Europe of Freedom and Democracy (EFD) group of Eurosceptic, radical right (e.g. the True Finns) and ethno-regionalist parties (e.g. the Lega Nord). UKIP is the only one of its nine parties to demand withdrawal from the EU. The EFD is a marriage of convenience providing the benefits of group status but allowing members to vote as they see fit. There is little coordination of positions in what is the EP's least cohesive group, with the Lega Nord frequently voting in favour of integration and UKIP against. ${ }^{21}$

The freedom of manoeuvre within the EFD did not satisfy all. Nikki Sinclaire, Mike Nattrass and Trevor Colman have left the EFD, the former having the whip withdrawn while the latter two remain UKIP MEPs. Sinclaire argues that group membership 'helps the EU to work' and that sitting with parties who do not favour withdrawal and have 'extremist views' compromises UKIP's position. ${ }^{22}$ However, $72 \%$ of survey respondents agreed/strongly agreed that 'UKIP MEPs should be part of a political group within the European Parliament'. Whether 'UKIP MEPs should be part of a transnational political party' provoked greater division: 35\% agreed/strongly agreed, and 35\% disagreed/strongly disagreed (see Table 1). Under Regulation (EC) No. 2004/2003, parties may gain additional EU funding by forming a 'European political party'. Farage argues that this would provide an additional $£ 1$ million but opponents fear that it would signal accommodation with European integration. The European Alliance for Freedom was established by a number of Eurosceptic politicians, including UKIP's Godfrey Bloom, in 2010 but that year's UKIP conference decreed that a decision on membership must be approved in a ballot of party members. In the 2011 ballot, $67 \%$ of party members rejected membership of a pan-European party.

This analysis provides further evidence of the difficulties Eurosceptics must overcome to make an impact in the EP. Problems include the ideological heterogeneity of Eurosceptic parties, divisions between 'soft' and 'hard' Eurosceptics, the fragility of Eurosceptic party groups, and questions about whether activism in the EP amounts to accommodation with the EU. ${ }^{23}$ 
Niche parties maintain their distinctive position by eschewing comprehensive policy platforms and focusing on novel issues that do not coincide with existing fault-lines. UKIP emerged when European integration was dividing the Conservatives and becoming a salient issue for an increasingly Eurosceptic electorate, but its salience has since declined. ${ }^{24}$ The main parties played a part in this. Labour deferred decisions and promised referendums on EMU and the Constitutional Treaty, ${ }^{25}$ while the Conservatives downplayed the issue after their 2001 'save the Pound' campaign. Media coverage of Europe has increased since the crisis in the euro zone but newspapers such as the Daily Mail and the Daily Telegraph tend to give Conservative Eurosceptics more positive coverage than UKIP, although the Daily Express (which supports withdrawal) is more favourable.

The low salience of the European issue provides an incentive for UKIP to broaden its appeal, but there are dangers in doing so. Attitudes to Europe are not simply captured by left-right position, so UKIP might deter some supporters if it promotes neo-liberal policies. As noted earlier, UKIP must also ensure that a wider platform does not dilute its core message because niche parties may suffer internal divisions and lose their core support if they moderate their radicalism on their core issue.

UKIP candidates are, unsurprisingly, united in support of the party's central objective: $99 \%$ of respondents agreed/strongly agreed that Britain should 'withdraw from the EU'. However, there has been debate about the mechanics of departure. The leadership position is that Britain should negotiate favourable terms for withdrawal (e.g. a free trade agreement), perhaps after a 'no' vote in a referendum. In the 2010 leadership contest, Tim Congdon proposed 'unconditional unilateral withdrawal', with a free trade agreement a consequence rather than condition for withdrawal. ${ }^{26} \mathrm{On}$ options after withdrawal, most respondents supported 'a stronger trade relationship' with the Commonwealth and NAFTA, and 'bilateral trade agreements with the EU'. Support for 'membership of the European Economic Area' was lower (62\% agreed/strongly agreed), reflecting concerns that members implement much EU law.

There is widespread support for broadening UKIP's narrative: $99 \%$ of respondents agreed/ strongly agreed that it should have 'a policy platform [that] encompasses a wide range of issues, built around the core theme of withdrawal from the EU'. But a lower proportion (67\%) disagreed/strongly disagreed with the proposition that UKIP's 'policy platform [should be] restricted to the core theme of withdrawal from the EU' (see Table 3).

[Table 3 about here]

Candidates were asked whether UKIP should campaign on eight specified policy areas (see Table 4). A referendum on EU membership, immigration and the economy received the strongest support. Two issues to feature in recent UKIP discourse, Islamic extremism and climate change scepticism, did not attract such ardent support but few disagreed that the party should campaign on them.

[Table 4 about here]

Further information on candidates' policy preferences was gauged from UKIP's website. Candidates provided two local issues of importance to supplement three from the party: 'stop paying the EU £45 million every day', 'take back control of Britain's borders' and 'bring the power to make UK laws back to Westminster'. 503 candidates provided a total of 994 statements. Excluding repetition of statements solely about the EU and immigration, employment was most frequently mentioned (123 statements), followed by housing and planning (104), crime (98) and taxation (90). The statements show how UKIP links EU membership to local issues such as post office closures and the 
construction of wind farms. Overall, UKIP candidates want the party to campaign on a wide range of issues but, beyond immigration and the economy, there is some variation on those regarded as most important.

\section{Political attitudes and party competition}

Candidates were asked to place themselves, UKIP, its voters and other parties on scales concerning attitudes to European integration and immigration. UKIP candidates are strongly Eurosceptic and see their party in the same light (see Table 5). They view UKIP voters as Eurosceptic, but not to quite the same degree. The BNP is regarded as Eurosceptic, but less so than UKIP, with Labour and particularly the Liberal Democrats seen as favouring further integration. On the 11 point scale, $25 \%$ of respondents placed the Conservatives on the Eurosceptic side (receiving scores of 0-4), but 58\% felt they support further integration (with scores of 6-10).

\section{[Table 5 about here]}

On immigration, respondents perceived their own views, UKIP's position and the views of its voters as similarly supportive of a tougher immigration policy (see Table 6). $72 \%$ placed themselves at the far end of the scale favouring a significant tightening of the regulation of immigration. There was no clear view on the Conservatives' position, although many respondents placed them near the centre. The BNP was seen as having a tougher position than UKIP. Responding to a separate question, twothirds agreed/strongly agreed that 'the presence of the BNP makes it more important that UKIP campaigns on immigration and community relations'.

\section{[Table 6 about here]}

The position of niche parties is best understood in terms of new issue cleavages. However, UKIP's relative position on the traditional left-right scale gains some significance if the party places more emphasis on issues other than European integration. On average UKIP candidates placed their party to the right of centre on a left-right scale, between the Conservatives and the BNP (see Figure 1). Very few placed it on either the left or the far right. Our coding of UKIP's 2010 manifesto using Comparative Manifestos Project methodology also positions UKIP on the centre right with a score of 5.03 where 0 is central and higher values represent more right-wing views. ${ }^{27}$ Only $36 \%$ of candidates positioned the Conservatives on the right. A plurality (45\%) located the BNP on the far right, although a minority $(22 \%)$ regarded it as left wing, presumably because of its interventionist and authoritarian policies. This split of opinion between the two extremes means that in Figure 1, the BNP's position is closer to the centre than it would otherwise be.

[Figure 1 about here]

\section{UKIP and the Conservatives}

UKIP has adopted both adversarial and accommodating positions towards the Conservatives. In adversarial mode, it has targeted the political space vacated by the Conservatives' move to the centre, purporting to be an authentic conservative voice on Europe and immigration, adopting policies shunned by the Tories (e.g. building grammar schools) and appealed to disaffected Conservatives to 'lend us your vote'. But an approach that is too adversarial could damage UKIP's prospects of attracting donations, defectors and votes. Kilroy Silk's 2004 declaration that UKIP should 'kill' the Conservatives saw donor Paul Sykes cut ties with the party. 
Farage offered to stand down candidates in the 2010 general election if the Conservatives promised a binding referendum on EU membership. This appeared to prioritise policy over office. But the offer was disingenuous in that it would likely expose Conservative divisions, could not have been easily delivered by the UKIP leadership, and was never likely to be accepted. There have also been periodic discussions on whether UKIP should field candidates in constituencies with a Eurosceptic MP. The 2004 conference voted to contest such seats. In Farage's first spell as leader, UKIP's position was that it would not stand against MPs who supported the Better Off Out (BOO) campaign, thereby improving the chances of maintaining a hard Eurosceptic presence in the House of Commons. But it would challenge non-incumbents who supported BOO because their position had not been tested in parliament, and non-BOO MPs as their party allegiance took precedence over their Euroscepticism.

The position was less watertight under Pearson who, as head of the Global Britain think tank, hoped to strengthen the wider Eurosceptic movement. UKIP chose not to stand against five Conservative and one Labour candidate. The latter, David Drew, was not aligned to BOO but UKIP challenged BOO supporter Austin Mitchell. Pearson angered some local associations by requesting publically that more candidates withdraw. None did and some threatened an extraordinary general meeting. Others felt Pearson was naïve when friends outside UKIP requested help. When asked whether UKIP should 'field candidates in a seat where a Eurosceptic Conservative is standing', survey respondents were divided: $48 \%$ agreed/strongly agreed it should, but $26 \%$ disagreed/strongly disagreed. A majority opposed 'an electoral pact with other Eurosceptic parties' and there was almost no support for a pact with the BNP.

The proposition that UKIP 'contest all seats' at the election was strongly supported ( $88 \%$ agreed/strongly agreed) (see Table 7). UKIP fielded 558 candidates but some were 'paper candidates' who did not actively campaign; 90 UKIP candidates spent no money between 1 January 2010 and polling day, and over half spent under $£ 1,000 .{ }^{28}$ Most lost their deposits but by fielding a record number of candidates, UKIP sought to cement its position as the fourth largest party and poll a million votes. It achieved the former, but narrowly failed on the latter. Much effort was focused on Buckingham where a high profile campaign was expected to boost the party's prospects elsewhere.

\section{[Table 7 about here]}

When asked 'from which party do you think UKIP is most likely to win votes in your constituency', $30 \%$ named the Conservatives and 30\% Labour. Those in the South West and South East were much more likely to cite the Conservatives, whereas Labour was more frequently chosen by those in the North West and Yorkshire. 51\% of respondents had been members of another party in the (sometimes distant) past: $30 \%$ had been Conservative members but only $4 \%$ Labour.

UKIP has had some difficulty in deciding how to approach competition with the Conservatives. While the bulk of respondents think UKIP should contest all seats, a substantial minority are unhappy about challenging Eurosceptic Conservatives. To probe further the challenges facing UKIP, we now assess the views of its supporters.

\section{Support for UKIP}

How closely aligned are UKIP candidates and voters, and does the broadening of the party narrative fit with the views of its voters? We address this using descriptive statistics and bivariate analyses of data from two surveys carried out by YouGov. One took place in the run up to the 2009 European elections and included over 32,000 respondents, more than 4,000 of whom declared a voting intention for UKIP. The second was carried out shortly after the 2010 general election (6-21 May) 
and includes just under 70,000 cases, with a little over 2,000 of these being UKIP voters. These data are from two different types of electoral contest and research suggests that European and national elections should be treated differently, with the former as second-order elections in which voters and parties are concerned mainly with national rather than EU issues. ${ }^{29}$ Small parties tend to perform better in these contests and governing parties worse. While we concentrate mainly on the general election data, the fact that a large number of respondents participated in both surveys means we can make some comparisons, in terms of vote choice, between the contests, using a dataset of those responding to both surveys, weighted for representativeness. We use the 2009 data mainly to measure attitudes to European integration as questions on this did not feature in the 2010 survey. Before looking at the social characteristics and political attitudes of UKIP voters, we briefly review the party's 2010 performance.

Aggregate analysis of UKIP's 2010 support shows that it performed best in areas with a high proportion of people aged over 65, fewer people with a degree and higher numbers of self-employed. Geographically, its best results were in non-urban southern England, particularly coastal areas. ${ }^{30}$ UKIP averaged $3.5 \%$ of the vote in the 558 constituencies in which it stood. In Buckingham, Farage won $17.4 \%$ in a seat where Labour and the Liberal Democrats did not stand. UKIP came third here and in three seats in the South West where Labour performed particularly poorly: North Cornwall, North Devon, and Torridge and West Devon. Deposits were saved in 100 constituencies, mainly in the West Midlands, South West and Eastern England. Correlations of constituency vote shares (Table 8) show that the UKIP's vote was positively correlated with that of the BNP and the Conservatives. Given that there were 255 seats in which UKIP stood but the BNP did not, these figures may underestimate the correlation between the two parties' vote share. ${ }^{31}$

\section{[Table 8 about here]}

Turning to UKIP's support at the individual level, Table 9 compares the social characteristics of UKIP voters and others, using data from the YouGov 2010 post-election survey. UKIP's 2010 voters are slightly older, more likely to be male, white and drawn from social classes C2, D and E, but less likely to have a degree, compared with voters for the three main parties. They are more likely to live in the East of England or South West than other voters, but less likely to live in Scotland or London. When compared with the BNP, UKIP voters are older, more likely to be female and more evenly spread across social grades. Much of this fits with analysis of UKIP's support at the 2009 European elections, except for the findings on social class which did little to explain UKIP support in $2009 .{ }^{32}$

\section{[Table 9 about here]}

Table 10 compares the attitudes of UKIP voters and supporters of other parties on European integration, immigration and trust in politicians. In line with the party's views, we find that UKIP voters agree more strongly, on average, that Britain should withdraw from the EU. The difference between UKIP and the BNP is small ( 0.2 points on the $1-5$ scale) but statistically significant $(\mathrm{p}<0.001)$. Also in line with the party's thinking are our findings that UKIP's voters are more likely to disagree that the EU promotes prosperity throughout Europe and more likely to agree that a great majority of decisions affecting daily lives are taken by the EU rather than Westminster. Consistent with this, analysis of voting in the 2009 European elections showed that Euroscepticism was the most powerful explanatory factor in the decision to vote UKIP. ${ }^{33}$

Table 10 also shows voters' attitudes to immigration using two questions from the YouGov European election survey. UKIP voters are more concerned about immigration, on average, than voters for the three main parties, but less so than those supporting the BNP in 2009. We find the same ordering, by party support, when we look at those general election voters who answered both 
the European and general election surveys. UKIP's focus on this issue looks astute in the light of these results. UKIP also campaigns on the lack of differences between the main parties. While the 2010 YouGov survey did not ask a question specifically on this, we can tap into this populism by looking at voters' views on the honesty of politicians. Here we find UKIP voters in 2010 rate elected politicians and general election candidates as less honest, on average, than do voters for the three main parties. BNP voters rate general election candidates equally as badly as do UKIP supporters and hold an even lower opinion of elected politicians.

\section{[Table 10 about here]}

Having noted that UKIP candidates believe that the party should campaign on a range of issues, we now examine the issues that UKIP voters see as most important. The 2010 YouGov survey asked what respondents thought was 'the single most important issue facing the country at the present time'. UKIP voters were most likely to cite immigration as the most important issue, followed by the economy and then Europe. ${ }^{34}$ Immigration also topped the list of most important issues for UKIP voters in the European election survey, so this result is not specific to their general election supporters. This adds further weight to the view that UKIP should move beyond a single-issue approach. UKIP links immigration to the EU by noting that Britain cannot impose controls on migration from Member States. Research on support for UKIP in 2009 showed that voters believing immigration policy should be decided by each country rather than at the EU level were more likely to support UKIP in comparison with Labour and the Conservatives. ${ }^{35}$

Given that UKIP performed much better in the European than general election and the differences between these types of contest, we also examine how its 2009 voters acted a year later. This is possible as $54 \%(n=17,535)$ of respondents to the 2009 YouGov survey also responded to the 2010 survey, including 2,626 of the 4,252 UKIP voters in the European election survey. The lower number of respondents in 2010 is due to some leaving the YouGov panel, and to non-response (i.e. some of those answering in 2009 chose not to respond to the 2010 survey). Of the respondents to the 2009 survey, only those who unsubscribed from the YouGov panel between the two surveys - a relatively small number - would not have been asked to complete the 2010 questionnaire. But the high degree of non-response in 2010 from among those that answered the 2009 survey is unlikely to be random. In order to deal with the biases that this large loss of respondents may introduce, YouGov produced a weight variable for those respondents who answered both surveys to ensure the representativeness of this sample. On the basis of these weighted data we find that $47 \%$ of UKIP's 2009 voters switched to the Conservatives at the general election, $17 \%$ to Labour, $16 \%$ to the Liberal Democrats and another $16 \%$ stayed with UKIP. UKIP thus benefitted considerably in 2009 from Conservative supporters 'lending their votes'.

When asked in the 2010 YouGov survey who they had voted for at the previous general election, $24 \%$ of UKIP's 2010 voters recalled also voting for UKIP in 2005 , while $23 \%$ claimed to have voted Conservative and 17\% Labour. We can also roughly gauge how much of the vote for the main parties might have gone to UKIP if voters had voted sincerely rather than tactically. Of those who said they voted Conservative but either really preferred another party or had voted tactically, one-third said they preferred UKIP, the largest proportion for any party. The equivalent figure for those voting Labour in 2010 was 7\% and 5\% for Liberal Democrat supporters. Combined with the evidence of vote switching between European and general elections, this suggests that UKIP have more to gain from Conservative than Labour supporters. ${ }^{36}$ Furthermore, when we look at UKIP general election voters' opinions of other parties, the Conservatives are the most favoured, with an average score of 5.6 on a scale where $0=$ 'strongly dislike' and $10=$ 'strongly like'. This compares with scores of 4.8 for the BNP and 3.5 for Labour. 
Are there other differences between UKIP's general election and European election voters? The rightmost column in Table 9 shows the social and demographic characteristics of UKIP's 2009 European election voters, based on the 2009 YouGov European election survey. Comparisons with UKIP's general election voters show little difference in terms of age, sex and regional distribution. The main difference concerns social class, where UKIP's general election supporters are more evenly spread across the categories, with smaller proportions of $\mathrm{AB}$ voters, similar proportions of $\mathrm{C} 1$ voters and somewhat larger proportions of those in groups D and E compared to UKIP voters in 2009. On political attitudes, using the sample of respondents who took part in both surveys, ${ }^{37}$ UKIP's general election voters have stronger anti-immigration and more populist views, on average, than those supporting them in European elections (with mean scores of 4.2 and 4.6 for the two immigration questions reported in Table 10). But when compared with BNP general election voters, UKIP supporters have weaker views on immigration and the dishonesty of politicians.

Ford et al. identified UKIP's 'core supporters' using a question in the 2009 YouGov European election survey about voting intentions at the general election. ${ }^{38}$ In the 2009 poll, $47 \%$ of those supporting UKIP in the European elections claimed that they also intended to vote for UKIP in the general election. Of those voters who also went on to answer YouGov's general election survey, after weighting, only $27 \%$ who had said in 2009 that they would vote UKIP at the general election actually did so. $29 \%$ voted Conservative and $20 \%$ Labour. Consistent with Ford et al.'s argument, we have shown that UKIP benefits from Conservative defectors at European elections and that UKIP's general election supporters have harder views on immigration and populism than their European election supporters. But our findings contrast with those of Ford et al. in that UKIP's general election supporters are similar in terms of age, sex and region to its European election supporters, and differ in these respects and in terms of social class from BNP voters (see Table 9). ${ }^{39}$ If UKIP's general election supporters are closer than their European election voters to those of the BNP in terms of attitudes, and to Labour in terms of demographics (although the latter is limited), this may be because of a political context in which a Labour government was particularly unpopular. But testing this argument is for future research.

\section{Conclusions}

In common with other niche parties, UKIP faces significant challenges if it is to secure parliamentary representation. The radical and distinctive appeal of niche parties on new issue cleavages may enable them to make an initial electoral breakthrough, but they have to broaden their appeal if they are to achieve their policy and office objectives. A key challenge for UKIP is thus to maintain its distinctive position on Europe while developing a broader platform and avoiding the internal divisions and loss of support that often follow if a niche party extends its focus at the expense of its core policy. The evidence presented here shows that the UKIP leadership and candidates recognise they must focus on issues beyond European integration, but there are some differences over what these issues should be. Differences are also evident on UKIP's relationship with Eurosceptic Conservatives, reflecting debates about how the policy goal of withdrawal from the EU might best be achieved. The defection to the Conservatives of David Campbell Bannerman, who had led UKIP's policy review, and criticism of party strategy from other MEPs illustrate the tensions that these issues provoke.

UKIP's position on European integration reflects the Eurosceptic views of its candidates and voters. This has delivered success in European elections, raising the party's profile and providing significant resources. The dilution of Conservative Euroscepticism within the coalition government and the crisis in the euro zone should provide favourable conditions for another strong UKIP performance in 
the 2014 European elections. A significant proportion of UKIP's 2009 European election support, however, returned to the Conservatives in 2010. UKIP's claim that a Conservative government will not deliver fundamental change in Britain's relationship with the EU may also bring more votes in a 2015 general election. Opinion polls register increased support for withdrawal, but Europe is unlikely to be a decisive issue for most voters. The extent to which UKIP can continue to win votes from disillusioned Labour supporters now that Labour is out of office will only become apparent over time.

Immigration is a key issue for both UKIP candidates and supporters, featuring prominently in the party's campaigns, has increased in salience in recent elections and is an issue on which the main parties appear vulnerable. Under Pearson, UKIP added a focus on Islamic extremism. A ban on wearing the burqa in public remains party policy but did not feature in UKIP's 2011 local and devolved elections manifestos. ${ }^{40}$ The combination of Islamophobia, anti-immigration policies, populism and Euroscepticism has brought electoral dividends for populist radical right parties. This is a serious strategic option for UKIP as it would help it to win over that sizeable tranche of voters who share these attitudes yet regard the BNP as a pariah party. ${ }^{41}$ But there are reputational risks. Following too closely in the footsteps of the radical right might contaminate the UKIP brand and repel wavering Conservative voters. UKIP candidates and voters are largely hostile to the BNP. UKIP has tried to dissociate itself from the BNP, not always successfully, by proclaiming itself a non-racist party and focusing on the constraints on immigration policy created by EU membership. With the BNP wracked by internal tensions, UKIP may gain further support from voters concerned about immigration without reproducing the xenophobia of the far right. Populist, anti-establishment messages also enable UKIP to tap into dissatisfaction with the main parties on issues such as immigration without having to develop an array of specific policies.

If UKIP is to persuade Eurosceptic Conservative supporters in particular to do more than lend their votes, it must not only raise the salience of the issue of Europe but also broaden its message. A narrative built around the theme of independence offers an alternative to the single issue and populist radical right strategies. It would include independence from the EU, the independence of citizens from excessive state intervention, and independent thinking on issues such as Europe, immigration and climate change where UKIP depicts itself as an alternative to elite consensus. Within this narrative, UKIP can also link EU membership to national and local issues that are of greater concern to voters. It has, for example, focused on the costs of membership, the impact of the Working Time Directive on the National Health Service, and how EU regulations shape local issues from job losses in manufacturing to the building of wind farms.

Niche parties such as UKIP must also strike an appropriate balance between national campaigns on their distinctive issue and the bottom-up development of their support base in target constituencies. Eurosceptic and populist radical right parties across Europe, often with dominant leaders, have gained support by focusing on popular concerns about issues neglected by mainstream parties. But niche parties that have won parliamentary seats have also built grassroots support in target areas. Under Farage, UKIP has followed the former path and this has brought rewards in European elections contested in multi-member regions. In common with other hard Eurosceptic parties, success in European elections has raised difficult questions about the extent to which UKIP engages with the European Parliament. The leadership now also recognises that UKIP must develop a longer-term strategy to build its local presence in areas where it has performed relatively well, win council seats and target Westminster constituencies. A well-funded campaign delivered second place in the Barnsley Central by-election but a disappointing showing in the 2011 local elections showed that UKIP still has much work to do. 


\section{Funding}

This work was supported by the Leverhulme Trust (grant number F/00 212/AD).

\section{Acknowledgements}

We are grateful to Joe Twyman of YouGov for making polling data available to us, answering questions about data collection and providing us with a weight variable for all respondents who answered both the 2009 and 2010 YouGov surveys. We thank the candidates who completed our surveys and those who, along with party officials and MEPs, granted us interviews. We also thank the reviewers for their constructive comments, and David Denver for his assistance with constituency-level voting data. 
Figure 1 UKIP candidates' mean positioning of UKIP and other parties on a left-right scale

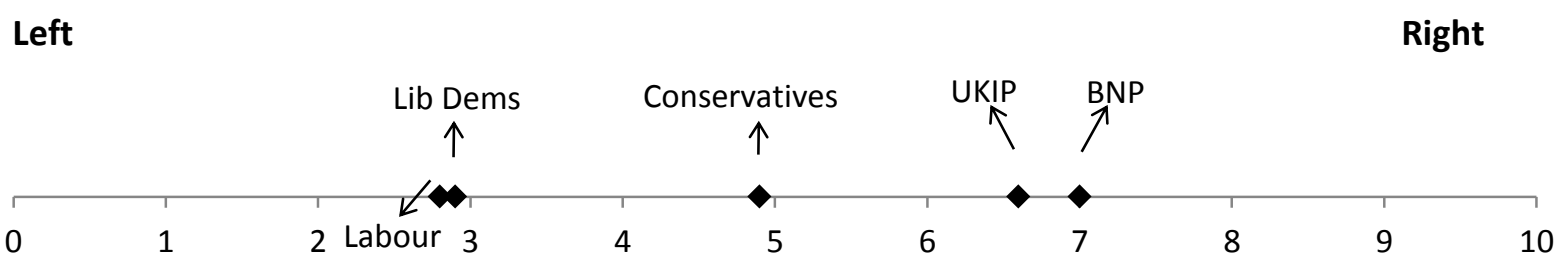

Note: the question asked 'In politics, people sometimes talk about parties and politicians as being on the left or right. Using the 0 to 10 scale below, where 0 means left and 10 means right, where would you place [list of parties and self-placement]?' 
1. Attitudes of UKIP general election candidates to UKIP's participation in the European Parliament and parties (\% of respondents)

\begin{tabular}{|c|c|c|c|c|c|}
\hline & $\begin{array}{l}\text { Strongly } \\
\text { agree }\end{array}$ & Agree & $\begin{array}{l}\text { Neither agree } \\
\text { nor disagree }\end{array}$ & Disagree & $\begin{array}{l}\text { Strongly } \\
\text { disagree }\end{array}$ \\
\hline $\begin{array}{l}\text { UKIP MEPs should take their } \\
\text { seats in the European } \\
\text { Parliament }\end{array}$ & 61 & 30 & 4 & 3 & 2 \\
\hline $\begin{array}{l}\text { UKIP MEPs should be part of } \\
\text { a political group in the } \\
\text { European Parliament }\end{array}$ & 40 & 32 & 19 & 7 & 2 \\
\hline $\begin{array}{l}\text { UKIP MEPs should be part of } \\
\text { a transnational political party }\end{array}$ & 17 & 18 & 29 & 17 & 18 \\
\hline
\end{tabular}

Note: Figures in this and other tables reporting candidate survey data may not sum to 100 because of rounding. The question asked 'How much do you agree or disagree with the following statements [statements listed as in table above]?

2. Attitudes of UKIP European election candidates to UKIP MEPs' roles (\% of respondents)

\begin{tabular}{lccccc}
\hline & $\begin{array}{c}\text { 5. Of great } \\
\text { importance }\end{array}$ & 4 & 3 & 2 & $\begin{array}{c}\text { 1. Of little } \\
\text { importance }\end{array}$ \\
\hline Working on EU legislation & 20 & 7 & 15 & 12 & 46 \\
Scrutiny of other EU institutions & 80 & 14 & 5 & 0 & 2 \\
$\begin{array}{l}\text { Articulation of important societal needs and } \\
\text { interests }\end{array}$ & 37 & 27 & 15 & 0 & 22 \\
Representation of the UK national interest & 84 & 7 & 0 & 0 & 9 \\
Articulation of the Eurosceptic case in the EP & 85 & 9 & 2 & 2 & 2 \\
Developing links with like-minded parties & 61 & 30 & 9 & 0 & 0 \\
\hline
\end{tabular}

Note: the question asked 'We are interested in your views on the work of UKIP MEPs. How important are the following? [see table for statements]' 
3. UKIP general election candidates' views on UKIP's role in British politics (\% of respondents)

\begin{tabular}{|c|c|c|c|c|c|}
\hline & $\begin{array}{c}\text { Strongly } \\
\text { agree }\end{array}$ & Agree & $\begin{array}{c}\text { Neither agree } \\
\text { nor disagree }\end{array}$ & Disagree & $\begin{array}{l}\begin{array}{l}\text { Strongly } \\
\text { disagree }\end{array} \\
\end{array}$ \\
\hline $\begin{array}{l}\text { As a party whose policy } \\
\text { platform encompasses a wide } \\
\text { range of issues, built around } \\
\text { the core theme of withdrawal } \\
\text { from the EU }\end{array}$ & 84 & 15 & 1 & 0 & 0 \\
\hline $\begin{array}{l}\text { As a party whose policy } \\
\text { platform is restricted to the } \\
\text { core theme of withdrawal } \\
\text { from the EU }\end{array}$ & 7 & 14 & 12 & 42 & 25 \\
\hline $\begin{array}{l}\text { As part of a broad } \\
\text { Eurosceptic social movement } \\
\text { mobilising public opinion }\end{array}$ & 35 & 38 & 12 & 9 & 7 \\
\hline $\begin{array}{l}\text { To put pressure on the } \\
\text { Conservative Party to adopt a } \\
\text { more Eurosceptic position }\end{array}$ & 29 & 29 & 18 & 7 & 11 \\
\hline
\end{tabular}

Note: the question asked 'How much do you agree or disagree with the following statements? In the medium term, UKIP's role in British politics should be: [see table for statements]' 
4. UKIP general election candidates' views of policies on which UKIP should campaign (\% of respondents)

\begin{tabular}{|c|c|c|c|c|c|}
\hline & $\begin{array}{c}\text { Strongly } \\
\text { agree }\end{array}$ & Agree & $\begin{array}{c}\text { Neither agree } \\
\text { nor disagree }\end{array}$ & Disagree & $\begin{array}{l}\begin{array}{l}\text { Strongly } \\
\text { disagree }\end{array} \\
\end{array}$ \\
\hline Civil liberties & 64 & 27 & 7 & 2 & 1 \\
\hline Climate change scepticism & 45 & 35 & 13 & 6 & 2 \\
\hline Economy & 82 & 18 & 1 & 0 & 0 \\
\hline Education & 62 & 33 & 5 & 0 & 0 \\
\hline Health & 57 & 36 & 5 & 1 & 0 \\
\hline Immigration & 82 & 16 & 2 & 0 & 0 \\
\hline Islamic extremism in the UK & 50 & 33 & 10 & 6 & 1 \\
\hline $\begin{array}{l}\text { A referendum on UK } \\
\text { membership of the European } \\
\text { Union }\end{array}$ & 91 & 8 & 0 & 0 & 1 \\
\hline
\end{tabular}

Note: the question asked 'How much do you agree or disagree that UKIP should campaign on: [list of policy areas as in table]?'

5. Attitudes towards European integration among UKIP general election candidates (\% of respondents)

\begin{tabular}{|c|c|c|c|c|c|c|c|c|c|c|c|c|}
\hline & $\begin{array}{c}\text { European } \\
\text { integration } \\
\text { has gone } \\
\text { much too } \\
\text { far } \\
0\end{array}$ & 1 & 2 & 3 & 4 & 5 & 6 & 7 & 8 & 9 & $\begin{array}{l}\text { The EU } \\
\text { should } \\
\text { become a } \\
\text { federal } \\
\text { state } \\
10\end{array}$ & $\begin{array}{l}\text { Mean } \\
\text { value }\end{array}$ \\
\hline Yourself & 89 & 6 & 3 & 1 & 0 & 0 & 0 & 0 & 0 & 0 & 0 & 0.2 \\
\hline Your party & 92 & 6 & 1 & 0 & 0 & 1 & 0 & 0 & 0 & 0 & 0 & 0.1 \\
\hline $\begin{array}{l}\text { Your party's } \\
\text { voters }\end{array}$ & 71 & 13 & 9 & 3 & 1 & 1 & 0 & 0 & 0 & 0 & 0 & 0.6 \\
\hline Conservative & 1 & 1 & 5 & 8 & 10 & 18 & 14 & 11 & 11 & 5 & 17 & 6.2 \\
\hline Labour & 1 & 0 & 0 & 1 & 3 & 10 & 9 & 13 & 19 & 13 & 32 & 7.9 \\
\hline Lib Dems & 1 & 0 & 1 & 0 & 2 & 1 & 3 & 3 & 11 & 17 & 60 & 9.0 \\
\hline BNP & 74 & 8 & 6 & 3 & 2 & 4 & 0 & 1 & 0 & 0 & 3 & 0.9 \\
\hline
\end{tabular}

Note: the question asked 'Thinking about the level of integration in the European Union, using the following scale where the end marked 0 means that European integration has gone much too far and the end marked 10 means that the European Union should become a federal state, where would you place [items listed in table]?' 
6. Attitudes towards immigration among UKIP general election candidates ( $\%$ of respondents)

\begin{tabular}{|c|c|c|c|c|c|c|c|c|c|c|c|c|}
\hline & $\begin{array}{c}\text { Regulation of } \\
\text { immigration } \\
\text { to the UK } \\
\text { should be } \\
\text { significantly } \\
\text { tightened } \\
0\end{array}$ & 1 & 2 & 3 & 4 & 5 & 6 & 7 & 8 & 9 & $\begin{array}{l}\text { Regulation of } \\
\text { immigration } \\
\text { to the UK } \\
\text { should be } \\
\text { significantly } \\
\text { relaxed } \\
10\end{array}$ & $\begin{array}{l}\text { Mean } \\
\text { value }\end{array}$ \\
\hline Yourself & 72 & 14 & 9 & 2 & 3 & 1 & 0 & 0 & 0 & 0 & 0 & 0.5 \\
\hline Your party & 70 & 17 & 10 & 3 & 0 & 0 & 0 & 0 & 0 & 0 & 0 & 0.5 \\
\hline $\begin{array}{l}\text { Your party's } \\
\text { voters }\end{array}$ & 67 & 18 & 10 & 4 & 1 & 0 & 0 & 0 & 0 & 0 & 0 & 0.6 \\
\hline Conservative & 2 & 5 & 10 & 13 & 10 & 19 & 11 & 9 & 7 & 5 & 9 & 5.2 \\
\hline Labour & 0 & 1 & 2 & 3 & 4 & 10 & 7 & 13 & 18 & 12 & 31 & 7.7 \\
\hline Lib Dems & 0 & 0 & 1 & 1 & 1 & 6 & 6 & 9 & 15 & 15 & 45 & 8.5 \\
\hline BNP & 92 & 3 & 2 & 0 & 1 & 0 & 0 & 0 & 0 & 0 & 2 & 0.3 \\
\hline
\end{tabular}

Note: the question asked 'Using the 0 to 10 scale below, where 0 means that regulation of immigration to the UK should be significantly tightened and 10 means that regulation of immigration to the UK should be significantly relaxed, where would you place [items listed in table]?'

7. UKIP general election candidates' views on UKIP's strategy at the 2010 general election: (\% of respondents)

\begin{tabular}{llllll}
\hline & $\begin{array}{l}\text { Strongly } \\
\text { agree }\end{array}$ & Agree & $\begin{array}{l}\text { Neither } \\
\text { agree nor } \\
\text { disagree }\end{array}$ & Disagree & $\begin{array}{l}\text { Strongly } \\
\text { disagree }\end{array}$ \\
\hline Contest all seats & 63 & 25 & 6 & 6 & 0 \\
$\begin{array}{l}\text { Concentrate on a few seats where winning } \\
\text { might be possible }\end{array}$ & 15 & 19 & 11 & 40 & 16 \\
$\begin{array}{l}\text { Field candidates in seats where a } \\
\begin{array}{l}\text { Eurosceptic Conservative candidate is } \\
\text { standing }\end{array}\end{array}$ & 26 & 22 & 26 & 22 & 4 \\
$\begin{array}{l}\text { Seek an electoral pact with other } \\
\text { Eurosceptic parties }\end{array}$ & 8 & 18 & 22 & 31 & 21 \\
\hline
\end{tabular}

Note: the question asked 'How much do you agree or disagree with the following statements? At the forthcoming general election, UKIP should: [statements listed in table]' 
8. Correlations between party vote shares at the constituency level in the 2010 general election

\begin{tabular}{lccc}
\hline & UKIP vote & BNP vote & Conservative vote \\
\hline BNP vote & $0.25^{* *}$ & - & - \\
Conservative vote & $0.34^{* *}$ & $-0.29^{* *}$ & - \\
Labour vote & $-0.30^{* *}$ & $0.40^{* *}$ & $-0.76^{* *}$ \\
Lib Dem vote & 0.02 & $-0.37^{* *}$ & $-0.09^{*}$ \\
Green vote & -0.06 & -0.11 & $-0.18^{*}$ \\
\hline
\end{tabular}

$* * \mathrm{p}<0.01, * \mathrm{p}<0.05$

Source: May 6th 2010 British General Election Constituency Results Release 5.0, available at www.pippanorris.com 
9. Social and geographical characteristics of UKIP voters compared to others

\begin{tabular}{|c|c|c|c|c|c|c|}
\hline & UKIP & BNP & Conservative & Labour & $\begin{array}{c}\text { Liberal } \\
\text { Democrat }\end{array}$ & $\begin{array}{c}\text { UKIP EP } \\
\text { voters } 2009\end{array}$ \\
\hline Age (years) & $53^{*}$ & 48 & 50 & 47 & 45 & 52 \\
\hline Female & $44^{*}$ & 34 & 50 & 54 & 54 & 45 \\
\hline \multicolumn{7}{|l|}{ Social grade } \\
\hline $\mathrm{AB}$ & $22^{*}$ & 14 & 34 & 27 & 30 & 35 \\
\hline $\mathrm{C} 1$ & $25^{*}$ & 24 & 29 & 27 & 32 & 26 \\
\hline $\mathrm{C} 2$ & $27 *$ & 31 & 20 & 22 & 19 & 17 \\
\hline DE & $27 *$ & 32 & 17 & 24 & 19 & 23 \\
\hline White ethnic origin & $99 *$ & 99 & 97 & 93 & 95 & \\
\hline \multicolumn{7}{|l|}{ Terminal education age } \\
\hline 18 or lower & $76^{*}$ & 81 & 64 & 62 & 50 & \\
\hline Greater than 18 & $21^{*}$ & 16 & 33 & 33 & 42 & \\
\hline $\begin{array}{l}\text { Currently at school or full-time } \\
\text { student }\end{array}$ & $3^{*}$ & 3 & 4 & 6 & 8 & \\
\hline \multicolumn{7}{|l|}{ Region } \\
\hline North East & 4 & 8 & 3 & 6 & 5 & 3 \\
\hline North West & 11 & 12 & 9 & 16 & 11 & 11 \\
\hline Yorkshire and the Humber & 8 & 16 & 7 & 10 & 8 & 9 \\
\hline East Midlands & $9^{*}$ & 11 & 9 & 8 & 7 & 9 \\
\hline West Midlands & 9 & 13 & 10 & 9 & 8 & 11 \\
\hline East of England & $13^{*}$ & 10 & 12 & 7 & 10 & 11 \\
\hline London & $8 *$ & 11 & 13 & 13 & 12 & 10 \\
\hline South East & $19^{*}$ & 7 & 19 & 8 & 16 & 16 \\
\hline South West & $13^{*}$ & 5 & 10 & 6 & 12 & 12 \\
\hline Wales & 5 & 5 & 4 & 6 & 5 & 4 \\
\hline Scotland & $2^{*}$ & 3 & 4 & 11 & 7 & 3 \\
\hline
\end{tabular}

Source: YouGov 2010 post-general election survey for all data except UKIP EP voters in 2009 which are taken from the YouGov 2009 European elections survey.

Notes: All figures are percentages apart from those for age. * indicates statistically significant differences between UKIP voters and all others at the $\mathrm{p}<0.01$ level. The 2009 survey classified respondents in terms of occupation rather than social grade (A, B, C1 etc.) so figures given in the rightmost column are for occupations equivalent to the social grades in the table, based on the Market Research Society's (2006) Occupation Groupings: A Job Dictionary, $6^{\text {th }}$ edition, http://www.mrs.org.uk/publications/publications.htm. 
10. Political attitudes of UKIP voters compared with others

\begin{tabular}{|c|c|c|c|c|c|}
\hline & $\begin{array}{l}\text { UKIP } \\
\text { voters }\end{array}$ & $\begin{array}{l}\text { Conservative } \\
\text { voters }\end{array}$ & $\begin{array}{c}\text { Labour } \\
\text { voters }\end{array}$ & $\begin{array}{c}\text { Liberal } \\
\text { Democrat } \\
\text { voters }\end{array}$ & BNP voters \\
\hline $\begin{array}{l}\text { The UK should withdraw completely from the European Union } \\
\text { (1=strongly disagree, } 5=\text { strongly agree) }\end{array}$ & 4.3 & 3.2 & 2.3 & 2.3 & 4.1 \\
\hline $\begin{array}{l}\text { The existence of the EU promotes prosperity throughout Europe } \\
\text { (1=strongly agree, } 5=\text { strongly disagree) }\end{array}$ & 4.1 & 3.4 & 2.6 & 2.7 & 3.9 \\
\hline $\begin{array}{l}\text { A great majority of the important decisions that affect our daily life are } \\
\text { taken by the European Union not by Britain's parliaments, assemblies or } \\
\text { councils ( } 1=\text { completely untrue, } 3=\text { completely true })\end{array}$ & 2.7 & 2.4 & 2.0 & 2.1 & 2.6 \\
\hline $\begin{array}{l}\text { Immigration in recent years has helped Britain's economy grow faster } \\
\text { than it would have done ( } 1=\text { agree strongly, } 5=\text { disagree strongly) }\end{array}$ & 4.0 & 3.6 & 3.0 & 3.0 & 4.4 \\
\hline $\begin{array}{l}\text { All further immigration to the UK should be halted ( } 1=\text { disagree strongly, } \\
5=\text { agree strongly) }\end{array}$ & 4.4 & 3.9 & 3.2 & 3.1 & 4.8 \\
\hline $\begin{array}{l}\text { Thinking back to the recent general election campaign, how honest do } \\
\text { you think most candidates were? ( } 1=\text { very honest, } 4=\text { not at all honest) }\end{array}$ & 3.1 & 2.4 & 2.5 & 2.6 & 3.1 \\
\hline $\begin{array}{l}\text { Overall how would you rate the standards of honesty and integrity of } \\
\text { elected politicians in Britain today? (1=very high, } 5=\text { very low) }\end{array}$ & 4.1 & 3.3 & 3.2 & 3.5 & 4.4 \\
\hline
\end{tabular}

Sources: questions on Euroscepticism and immigration are taken from the 2009 YouGov European election survey, those on trust in politicians are from the 2010 YouGov post-election survey.

Note: the difference in means between UKIP and voters for each of the parties on each question is statistically significant at the $p<0.01$ level except for UKIP and the BNP on the honesty of general election candidates, where the mean responses are the same. 
${ }^{1}$ P. Taggart and A. Szczerbiack 'Theorising Party-Based Euroscepticism: Problems of Definition, Measurement and Causality', in P. Taggart and A. Szczerbiack (eds.), Opposing Europe. The Comparative Party Politics of Euroscepticism. Volume 2, Oxford University Press, 2008, pp.247-8.

2 S. Usherwood, 'The Dilemmas of a Single-Issue Party - the UK Independence Party', Representation, 44, 2008, 255-64

${ }^{3}$ B. Meguid, 'Competition between Unequals: The Role of Mainstream Party Strategy in Niche Party Success', American Political Science Review, 99, 2005, 347-59.

${ }^{4}$ J. Adams, M. Clark, L. Ezrow and G. Glasgow, 'Are Niche Parties Fundamentally Different from Mainstream Parties? The Causes and Electoral Consequences of Western European Parties' Policy Shifts, 1976-98', American Journal of Political Science, 50, 2006, 513-29.

${ }^{5}$ M. Wagner, 'Defining and Measuring Niche Parties', Party Politics, Online First, 18 May 2011, p.3, doi:10.1177/1354068810393267.

${ }^{6}$ UKIP is not included in the 2006 Benoit and Laver expert study employed by Wagner, and the UK is not included in his analysis of Comparative Manifesto Project data.

${ }^{7}$ C. B. Jensen and J.-J. Spoon, 'Thinking Locally, Acting Supranationally: Niche Party Behaviour in the European Parliament', European Journal of Political Research, 49, 2010, 174-201.

${ }^{8}$ P. Taggart and A. Szczerbiack, op. cit., note 1, p.248.

${ }^{9}$ K. Strøm and W. C. Müller, 'Political Parties and Hard Choices', in K. Strøm and W. C. Müller (eds.), Policy, Office or Votes? How Political Parties in Western Europe make Hard Decisions, Cambridge University Press, 2000, pp.1-35.

${ }^{10}$ L. Ezrow, 'On the Inverse Relationship between Votes and Proximity for Niche Parties', European Journal of Political Research, 47, 2008, 206-20.

${ }^{11}$ B. Meguid, op.cit, note 3.

12 J.-J. Spoon, 'Holding Their Own: Explaining the Persistence of Green Parties in France and the UK', Party Politics, 15, 2009, 615-34.

${ }^{13}$ G. Benedetto, 'Explaining the Failure of Euroscepticism in the European Parliament', in A. Szczerbiak and P. Taggart (eds.), op. cit., note 1, pp.127-50

${ }^{14}$ A. Abedi and T. Lundberg 'Doomed to Failure? UKIP and the Organisational Challenges facing Right-Wing Populist Anti-Political Establishment Parties', Parliamentary Affairs, 62, 2009, 72-87.

${ }^{15}$ Bob Spink claimed to be a UKIP MP after leaving the Conservatives in 2008, but subsequently described himself as an independent. He stood as an independent in Castle Point in 2010, polling $27 \%$ of the vote, and did not face a UKIP challenger.

${ }^{16}$ C. Mudde, Populist Radical Right Parties in Europe, Cambridge University Press, 2007.

${ }^{17}$ A. Abedi and T. Lundberg, op. cit., note 14. 
${ }^{18}$ www.surveymonkey.com

${ }^{19}$ For the European election survey, 65 candidates were sent the survey electronically, four the postal survey only, and 36 both after email contact proved unsuccessful. 27 candidates completed the electronic survey and 20 the postal version. Of the 558 general election candidates, 483 were contacted via email and 50 by post. We were unable to contact 25 candidates. 295 valid responses were received: 282 electronic surveys and 13 postal.

${ }^{20}$ For the regions, $\mathrm{p}=0.72$ and for sex, $\mathrm{p}=0.37$ indicating very strong support for the null hypothesis that the distribution of regions and sex in the sample is the same as in the population of UKIP candidates.

${ }^{21}$ Data at Votewatch.eu show that at the end of the 2010-11 session, the cohesion rate for the EFD was 0.49 compared to more than 0.80 for the other 6 groups.

www.votewatch.eu/cx_european_party_groups.php [accessed 20.07.11].

22 'Why UKIP should leave the Europe of Freedom and Democracy (EFD) Group', 19 January 2010, www.yourmep.org/freedom.html [accessed 22.01.10].

${ }^{23}$ G. Benedetto, op. cit., note 13 .

${ }^{24}$ B. Clements and J. Bartle, 'The European Issue and Party Choice at British General Elections, 1974-2005', Journal of Elections, Public Opinion and Parties, 19, 2009, 377-411.

${ }^{25}$ K. Oppermann, 'The Blair Government and Europe: the Policy of Containing the Salience of European Integration', British Politics, 3, 2008, 156-82.

${ }^{26}$ Agreement between Tim Congdon and Gerard Batten, 17 September 2010, www.timcongdon4ukip.com/docs/agreement.pdf [accessed 20.09.11].

${ }^{27}$ Scores from Comparative Manifesto Project data ( http://manifestoproject.wzb.eu/) for 2010 place the Conservatives at 17.54, the Liberal Democrats at 4.66 and Labour at -1.5 on the same left-right scale.

${ }^{28}$ Electoral Commission, 'Detailed Data on Expenditure and Donations', www.electoralcommission.org.uk/party-finance/party-finance-analysis/campaign-expenditure/ukparliamentary-general-election-campaign-expenditure3 [accessed 28.07.11].

${ }^{29}$ K. Reif and H. Schmitt, 'Nine Second-Order National Elections: a Conceptual Framework for the Analysis of European Election Results', European Journal of Political Research, 8, 1980, 3-44.

${ }^{30}$ J. Curtice, S. Fisher and R. Ford, 'Appendix 2: the Results Analysed', in D. Kavanagh and P. Cowley, The British General Election of 2010, Palgrave, 2010, p.404.

${ }^{31}$ We are grateful to one of the reviewers for pointing out that UKIP's increase in vote share from 2005 to 2010 on average was lower in seats where the BNP stood in 2010 but did not stand in 2005 , compared with those where it stood in both contests or did not stand in 2010. This indicates that the presence of BNP candidates may reduce UKIP's vote share.

${ }^{32}$ R. Whitaker and P. Lynch, 'Explaining Support for the UK Independence Party at the 2009

European Elections', Journal of Elections, Public Opinion and Parties, 21, 2011, 359-79. 
${ }^{33}$ R. Whitaker and P. Lynch, op. cit., note 32; R. Ford, M. Goodwin and D. Cutts, 'Strategic Eurosceptics and Polite Xenophobes: support for the UK Independence Party (UKIP) in the 2009 European Parliament Elections', European Journal of Political Research, 2011, forthcoming.

${ }^{34}$ The same ranking of issues among UKIP voters was found in the 2010 British Election Study internet pre-campaign panel survey.

${ }^{35}$ R. Whitaker and P. Lynch, op. cit., note 32.

${ }^{36}$ D. Sanders, H. Clarke, M. Stewart and P. Whiteley, 'Simulating the Effects of the Alternative Vote in the 2010 General Election', Parliamentary Affairs, 64, 2011, p.12, note that UKIP was the second preference of $29 \%$ of Conservative voters but only $9 \%$ of Labour voters in England, while $49 \%$ of the second preferences of UKIP voters were for the Conservatives, $17 \%$ for the BNP and only $8 \%$ for Labour.

${ }^{37}$ As there were no questions specifically on immigration in the 2010 survey, we are only able to measure UKIP general election voters' views on these issues for those who also answered the European election survey.

${ }^{38}$ R. Ford et al., op. cit., note 29.

${ }^{39}$ Differences between UKIP and BNP general election voters in terms of age, sex, social grade, education level and region are statistically significant at the $\mathrm{p}<0.01$ level.

${ }^{40}$ Abhijit Pandya, UKIP's candidate in the Leicester South by-election, was criticised by some in the party for his Islamophobic statements. See 'Sack Abhijit Pandya', http://bloggers4ukip.blogspot.com/2011/04/sack-abhijit-pandaya.html [accessed 29 April 2011].

${ }^{41}$ R. Ford et al., op. cit., note 29. 